УДК 004.42:001.895:378.14

Олег Маслій, кандидат педагогічних наук, старший науковий співробітник,

Військова академія, м. Одеса

ORSID 0000-0003-2809-2763

DOI: $10.33099 / 2617-1775 / 2019-02 / 99-110$

\title{
ПРОГРАМА Й МЕТОДИКА ДОСЛІДНО-ЕКСПЕРИМЕНТАЛЬНОӤ РОБОТИ ЩОДО РЕАЛІЗАЦІЇ ПЕДАГОГІЧНОЇ СИСТЕМИ ПРОФЕСІЙНОЇ ПІДГОТОВКИ МАЙБУТНІХ ОФІЦЕРІВ РАКЕТНО- АРТИЛЕРІЙСЬКОГО ОЗБРОЄННЯ
}

В статті наведено критерії та показники оиінювання ефективності авторської педагогічної системи професійної підготовки майбутніх офіцерів ракетно-артилерійського озброєння; описано результати аналізу професійної діяльності молодих офічерів ракетноартилерійського озброєння $\square$ випускників вищих військових навчальних закладів, які було обрано базою експериментального дослідження; представлено алгоритм проведення експерименту щуодо створення та впровадження у навчальний процес вищих військових навчальних закладів зазначеної системи, який передбачав 4 етапи (підготовчий, констатувальний, формувальний, узагальню вальний); докладно відображено результати кожного етапу експериментальної роботи, крім узагальнювального.

Ключові слова: вища військова освіта; наукове дослідження; критерії та показники оцінювання ефективності педагогічної системи.

Постановка проблеми. 3 появою нових вимог, що пред'являються до професійної підготовки випускників вищих військових навчальних закладів (ВВН3) у зв'язку зі збройним конфліктом на сході держави та нестабільною світовою політичною обстановкою, гостро постає проблема готовності військових фахівців до професійної діяльності в сучасних умовах розвитку Збройних сил (3С) України. Готовність майбутніх офіцерів ракетноартилерійського озброєння до професійної діяльності є особистісною підставою професіоналізму військовослужбовців, що має розвиватися в процесі навчання у військових закладах вищої освіти. Практика підготовки курсантів до професійної діяльності є відносно стійкою, оскільки в освітньому процесі тривалий час не відбувалися масштабні зміни, але водночас, як показало діагностичне дослідження, досить суперечливою.

Підвищення ефективності підготовки офіцерських кадрів для військ ракетно-артилерійського озброєння ми пов'язуємо з впровадженням в практику ВВНЗ авторської педагогічної системи професійної підготовки майбутніх офіцерів ракетно-артилерійського озброєння, яка має на меті саме формування зазначеної готовності. Але створення такої системи потребує, перш за все, проведення науково-педагогічних досліджень, які у змістовому вимірі мають різний характер і рівні (емпіричний, теоретичний, практичний), які нерозривно пов'язані між собою та утворюють цілісну динамічну систему наукового пізнання. 
Аналіз останніх досліджень і публікацій. На думку С. Максимюка, наукове дослідження - це особлива форма процесу пізнання, систематичне цілеспрямоване вивчення об'єктів, що завершується формуванням нового знання про досліджуваний об'єкт [9, с. 48], а складовою педагогічного дослідження $є$ педагогічний експеримент, який впливає на професійну підготовку майбутніх офіцерів ракетно-артилерійського озброєння.

Незважаючи на значну кількість наукових праць 3 організації, проведення та опрацювання результатів експерименту, єдиних вимог до такого виду діяльності не існує. Ученими і практиками використовується підхід, запропонований С. Гончаренком, щодо необхідності такої його організації, яка б давала можливість:

- продемонструвати зв'язки між досліджуваними явищами без порушення його цілісності;

- здійснити якісний аналіз і якомога точніше кількісне вимірювання як внесених у педагогічний процес змін, так і його результатів [5].

Запропонована організація педагогічного експерименту забезпечується змінами або відтворенням явища 3 метою його вивчення в найбільш сприятливих, чітко фіксованих і контрольних умовах [7, с. 107]. Характерною особливістю педагогічного експерименту $\epsilon$ те, що він дозволяє активно втручатися в ситуацію досліднику, який здійснює планомірне маніпулювання однією або кількома змінними (чинниками) та реєструвати супутні зміни в поведінці об' єкта, що вивчається [5, с. 112].

Результати наукових досліджень (А. Ашеров [1], С. Гончаренко [5], Г. Сльникова [6], В. Загв'язинський [7], П. Лузан [8] та ін.) підтверджують актуальність питань щодо організації та проведення емпіричних досліджень. Узагальнюючи погляди зазначених науковців, зазначимо, що під час здійснення наукового пошуку, методиці дослідження відведено провідну роль, оскільки вона містить сукупність методів, прийомів і способів, що використовуються для дослідження педагогічного явища чи процесу.

Метою статті $\epsilon$ оприлюднення програми й методики дослідноекспериментальної роботи щодо реалізації педагогічної системи професійної підготовки майбутніх офіцерів ракетно-артилерійського озброєння.

Методи дослідження: аналіз, синтез, систематизація наукової педагогічної літератури, нормативних документів, узагальнення. анкетування.

Виклад основного матеріалу. Зважаючи на те, що визначеної послідовності проведення педагогічного експерименту немає, окреслимо стратегію дослідження. У представленому дослідженні дотримувалися такого алгоритму:

- планування - передбачає складання програми експериментального дослідження, вибір конкретних методів і параметрів його проведення;

- організація педагогічного експерименту - включає визначення репрезентативної вибірки для сукупності явищ і процесів, що досліджуються;

- проведення педагогічного експерименту - що передбачає вивчення причинно-наслідкових зв'язків; 
- інтерпретація отриманих результатів - включає кількісно-якісний аналіз результатів педагогічного експерименту, опис отриманих результатів та їх інтеграцію в освітній процес, визначення ефективності експериментальної роботи.

Грунтуючись на набутому досвіді, виходячи зі завдань власного дослідження, кожен дослідник розробляє свою критеріальну базу, показники i методику оцінювання наукових результатів. Результати аналізу підходів різних авторів до розробки критеріїв і показників результативності досліджуваних процесів [2; 4; 10], аналіз сутності та структури покращення процесу професійної підготовки майбутніх офіцерів ракетно-артилерійського озброєння і підсумків обговорень в процесі бесід з командуванням 3С України і науковопедагогічними працівниками експериментальних ВВНЗ, дозволили виробити критерії і показники оцінювання ефективності досліджуваного процесу.

3 метою оцінювання ефективності педагогічної системи професійної підготовки майбутніх офіцерів ракетно-артилерійського озброєння були визначені наступні критерії: цільовий, діяльнісний, особистісний, результативний (табл. 1).

В якості основного, визначального критерію виділили цільовий, як головний критерій цільової спрямованості, що виступає як показник відповідності функціонування процесу професійної підготовки у майбутніх офіцерів ракетно-артилерійського озброєння, його змісту, методів, прийомів і засобів педагогічного впливу цілям підготовки військових фахівців Сухопутних військ ЗС України.

Таблиця 1

Критерії оцінювання ефективності педагогічної системи професійної підготовки майбутніх офіцерів ракетно-артилерійського озбросння

\begin{tabular}{|c|c|}
\hline Критерії & Показники \\
\hline Цільовий & $\begin{array}{l}\text { - моделювання області професійної діяльності майбутніх офіцерів } \\
\text { ракетно-артилерійського озброєння; } \\
\text { - відображення цілей в нормативних документах, періодичність їх } \\
\text { удосконалення; } \\
\text { - планування змісту занять } 3 \text { урахуванням міждисциплінарних } \\
\text { зв'язків і кваліфікаційних вимог до рівня підготовки курсантів; } \\
\text { - введення в зміст дисциплін професійної підготовки матеріалу, що } \\
\text { відображає сучасний рівень розвитку військової науки, техніки, } \\
\text { технологій, сучасних високотехнологічних зразків озброєння та } \\
\text { військової техніки. }\end{array}$ \\
\hline Діяльнісний & $\begin{array}{l}\text { - відповідність застосовуваних на заняттях форм, методів, засобів } \\
\text { навчання цілям, завданням і специфіці професійної діяльності; } \\
\text { - включення в практику проведення занять практичних, } \\
\text { ситуативних, нестандартних завдань за посадовим призначенням; } \\
\text { - рівень професійної підготовки науково-педагогічних працівників; } \\
\text { - використання технологій професійно-орієнтованого навчання в } \\
\text { освітньому процесі ВВНЗ. }\end{array}$ \\
\hline Особистісний & $\begin{array}{l}\text { - вираженість професійно-ціннісних орієнтацій; } \\
\text { - наявність } \quad \text { мотивів, як усвідомленої потреби } \quad \text { здійснювати }\end{array}$ \\
\hline
\end{tabular}




\begin{tabular}{|c|c|}
\hline & $\begin{array}{l}\text { професійну діяльність, самовдосконалюватися; } \\
\text { - оволодіння змістом таких понять і категорій як: «професійна } \\
\text { компетентність», «професійний обов'язок»; } \\
\text { - рівень сформованості вольових якостей курсантів, необхідних для } \\
\text { здійснення професійної діяльності в умовах, наближених до } \\
\text { бойових. }\end{array}$ \\
\hline Результативний & $\begin{array}{l}\text { - рівень сформованості професійних компетентностей в області } \\
\text { організаційно-управлінської (повсякденної) діяльності; } \\
\text { - рівень сформованості професійних компетентностей в області } \\
\text { бойового застосування ракетного та артилерійського озброєння; } \\
\text { - рівень сформованості професійних компетентностей в області } \\
\text { логістичної та експлуатаційної діяльності; } \\
\text { - рівень сформованості професійних компетентностей в області } \\
\text { організації і ведення інформаційної роботи. }\end{array}$ \\
\hline
\end{tabular}

Показники діяльнісного критерію характеризують відповідність застосовуваних форм, методів, засобів навчання задачам i специфіці професійної діяльності випускників ВВНЗ.

Особистісний критерій визначає рівень розвитку емоційно-вольових якостей курсантів, необхідних для успішної військово-професійної діяльності, прояви інтересу до обраної професії, оволодіння змістом таких понять i категорій, як «професійний обов'язок», «професійна компетентність» тощо.

Результативний критерій надає об'єктивні показники - рівень готовності майбутніх офіцерів РАО до професійної діяльності, оцінюваний за наявністю у курсантів знань, умінь і навичок в області організаційноуправлінської діяльності; бойового застосування ракетно-артилерійського озброєння (від мінометів до ракетних комплексів) і бойової підготовки підрозділів; експлуатаційної діяльності; організації та ведення інформаційної роботи.

3 метою проведення експериментального дослідження щодо професійної підготовки майбутніх офіцерів ракетно-артилерійського озброєння було здійснено аналіз сучасних методів психолого-педагогічного діагностування якісних і кількісних характеристик психологічних явищ, що супроводжують професійну діяльність військових фахівців і демонструють високий рівень фахових здібностей в особливий період та у мирний час.

Експериментальне дослідження передбачало:

- теоретичний аналіз проблеми професійної підготовки майбутніх офіцерів ракетно-артилерійського озброєння; курсантів;

- вивчення практики вдосконалення професійної компетентності у

- вибір об'єкта і предмета дослідження;

- розроблення гіпотези і методики експериментального дослідження;

- перевірку навчально-методичного забезпечення 3 професійної підготовки майбутніх офіцерів ракетно-артилерійського озброєння;

- визначення ефективності педагогічної системи професійної підготовки майбутніх офіцерів ракетно-артилерійського озброєння. 
3 метою вирішення цих завдань планувалося виявити:

- якість навчально-методичного забезпечення з професійної підготовки майбутніх офіцерів ракетно-артилерійського озброєння;

- рівень готовності курсантів до професійної діяльності, самовдосконалення особистісних якостей, що забезпечують іï прояв у майбутній професійній діяльності.

Дослідження проводили впродовж 2012-2019 рр. кількома етапами наукового пошуку.

На першому (теоретико-аналітичний) етапі (2012р.) - здійснено вивчення філософської, психолого-педагогічної, спеціальної літератури 3 досліджуваної проблеми; системний аналіз діяльності офіцерів ракетноартилерійського озброєння в сучасних умовах; актуалізацію окресленої проблеми, формулювання робочої гіпотези; конкретизація мети, визначення завдань; розроблення методики дослідження, добір методів його здійснення; накопичення емпіричного матеріалу; обгрунтування методологічних засад професійної підготовки майбутніх офіцерів ракетно-артилерійського озброєння.

На другому (діагностично-пошуковий) етапі (2012-2014рp.) проведено аналіз компонентів становлення майбутніх офіцерів ракетноартилерійського озброєння в освітньому середовищі ВВНЗ; розробку критеріїв і показників сформованості професійної компетентності майбутніх офіцерів ракетно-артилерійського озброєння; дослідно-експериментальну перевірку особливостей і стану готовності майбутніх офіцерів ракетно-артилерійського озброєння до професійної діяльності; визначення та обгрунтування педагогічних умов формування професійної компетентності майбутніх офіцерів ракетно-артилерійського озброєння; обгрунтування педагогічної системи професійної підготовки майбутніх офіцерів ракетно-артилерійського озброєння; створення спеціальних курсів, тематичних планів i програм, авторської методики і методичного забезпечення з урахуванням педагогічних умов і сутнісно-структурної характеристики професійної підготовки майбутніх офіцерів ракетно-артилерійського озброєння; уточнення завдань і методів дослідження; підготовка формувального етапу педагогічного експерименту.

На третьому (експериментально-дослідний) етапі (2015-2018рp.) здійснили експериментальну перевірку робочих гіпотез, концептуальних положень, педагогічної системи професійної підготовки майбутніх офіцерів ракетно-артилерійського озброєння та іï методичного супроводу; аналіз проміжних результатів; корекцію експериментальних та авторських методик і науково-методичного забезпечення, їх апробацію в освітньому середовищі вищих військових навчальних закладів.

На четвертому (узагальнювальний) етапі (2018-2019 рр.) - виконано опрацювання та систематизацію результатів, одержаних у процесі педагогічного експерименту; узагальнено результати дослідження, їх порівняння з прогнозованими; сформульовано загальні висновки педагогічного дослідження; визначено перспективи подальших наукових розвідок з означеної проблеми; оформлено матеріали науково-дослідної роботи. 
Експериментальну базу дослідження склали такі ВВНЗ: Військова академія (м. Одеса), Національна академія Національної гвардії України (м. Харків), Харківський університет Повітряних Сил імені Івана Кожедуба, Інститут Військово-Морських Сил Національного університету «Одеська морська академія», Військовий інститут танкових військ Національного технічного університету «Харківський політехнічний інститут», Чернівецький національний університет імені Юрія Федьковича (кафедра військової підготовки), які здійснюють підготовку військових фахівців для Збройних Сил України, що дозволило дотриматися репрезентативності вибірки.

Дотримання природних умов щодо проведення педагогічного експерименту зумовило внесення в процес змін відповідно до завдань дослідження i припущень без порушення його цілісності. Здійснений педагогічний експеримент передбачав кількісний і якісний аналіз внесених в освітній процес змін та отриманих результатів.

В процесі проведення педагогічного експерименту, а також встановлення закономірностей, що притаманні досліджуваному явищу, визначали його адекватність, та здійснювали їх перевірку через апробацію на практиці. Закономірностям властива повторюваність, оскільки вони мають емпіричний характер. Апробація авторської педагогічної системи професійної підготовки майбутніх офіцерів ракетно-артилерійського озброєння в процесі вивчення дисциплін професійної (загально-професійної, військово-професійної, професійно-спеціальної) підготовки спрямовувалася на забезпечення їх ефективності. Особливістю експериментального дослідження $\epsilon$ його спрямованість на курсантів вищих військових навчальних закладів.

Складність і багатофакторність явища готовності майбутніх офіцерів ракетно-артилерійського озброєння до професійної діяльності зумовили комплексний характер педагогічного експерименту, визначення впливу зовнішніх i внутрішніх чинників на $\dddot{\text { ii }}$ формування. 3 цією метою обгрунтовувалася й аналізувалася педагогічна система професійної підготовки майбутніх офіцерів ракетно-артилерійського озброєння, простежувалися зв'язки між ऑї елементами, фіксувалися й опрацьовувалися попередні результати.

В контексті педагогічного експерименту проводилася регулярна робота в частинах і підрозділах Сухопутних військ ЗСУ, дисертант відряджався у військові частини, де проходять службу випускники ВВНЗ, на базі яких проводився педагогічний експеримент. Методом анкетування командирів військових частин і підрозділів аналізувалася професійна діяльність молодих офіцерів (військовий стаж до 5-ти років) ракетно-артилерійського озброєння (табл. 2), здійснювалося спостереження за курсантами, що проходять військове стажування безпосередньо у військових частинах. 3 командуванням військових частин і підрозділів обговорювалися проблеми, з якими стикаються випускники вищих військових навчальних закладів під час виконання посадових обов'язків. 
Результати аналізу професійної діяльності молодих офіцерів ракетноартилерійського озбросння $(\mathbf{n}=390)$

\begin{tabular}{|l|l|l|l|l|l|}
\hline Якості, що характеризуються & \multicolumn{4}{l}{ Рівень розвитку якостей, \% } \\
\cline { 2 - 6 } & високий & достатній & середній & низький \\
\hline $\begin{array}{l}\text { Здатність оцінювати обстановку i } \\
\text { приймати правильні рішення }\end{array}$ & 5,2 & 76,8 & 18,0 & - \\
\hline $\begin{array}{l}\text { Здатність ставити бойові задачі та } \\
\text { керувати діями підлеглих }\end{array}$ & 2,4 & 71,0 & 24,6 & 2,0 \\
\hline $\begin{array}{l}\text { Готовність до ведення бойової роботи } \\
\text { в екстремальних умовах }\end{array}$ & 7,8 & 67,4 & 22,9 & 1,9 \\
\hline $\begin{array}{l}\text { Здатність проводити тактико- } \\
\text { оперативну підготовку з особовим } \\
\text { складом }\end{array}$ & 1,9 & 66,1 & 30,7 & 1,3 \\
\hline $\begin{array}{l}\text { Здатність вирішувати інформаційні } \\
\text { задачі за допомогою відповідного } \\
\text { програмного забезпечення }\end{array}$ & 15,2 & 70,2 & 13,1 & 1,5 \\
\hline
\end{tabular}

Метою педагогічного експерименту була перевірка ефективності заходів комплексного педагогічного впливу на досліджуваний процес, а також обгрунтування основних шляхів та умов підвищення його ефективності.

Для досягнення поставленої мети були вирішені наступні завдання:

- проведено аналіз сучасного стану професійної підготовки майбутніх офіцерів ракетно-артилерійського озброєння, уточнено іiі сутність і зміст, практика здійснення;

- обгрунтовано концептуальні положення професійної підготовки майбутніх офіцерів ракетно-артилерійського озброєння;

- визначено педагогічні умови для створення експериментальної педагогічної системи професійної підготовки військових фахівців;

- розроблено авторську педагогічну систему професійної підготовки майбутніх офіцерів ракетно-артилерійського озброєння та впроваджено іiі в освітній процес експериментальних ВВНЗ;

- виявлено, обгрунтовано та експериментально перевірено основні шляхи та умови підвищення ефективності процесу професійної підготовки майбутніх офіцерів ракетно-артилерійського озброєння.

Вивчення готовності майбутніх офіцерів ракетно-артилерійського озброєння до професійної діяльності, іiі стану і можливостей розвитку досліджуваного педагогічного явища передувало процесу наукового пошуку. 3 огляду на це, педагогічний експеримент проводився у військових закладах вищої освіти і включав три взаємопов'язаних етапи (рис. 1): підготовчий, констатувальний і формувальний.

В ході підготовчого етапу відбувалося осмислення проблеми; визначалася ступінь ії розробленості; уточнювалися цілі, завдання і формулювання гіпотези дослідно-експериментальної роботи; проводився науковий аналіз опублікованих монографій, дисертаційних робіт, науковопедагогічної, військово-спеціальної літератури, нормативних документів 3 тематики дослідження; вивчалася педагогічна практика формування 
професійної компетентності у курсантів під час навчання у ВВН3; аналізувалася існуюча і перспективна практика вивчення передового досвіду професійної підготовки майбутніх офіцерів ракетно-артилерійського озброєння в освітньому процесі ВВН3, визначалися напрями педагогічного експерименту; розроблялися критерії i показники оцінювання ефективності експериментальних заходів цілеспрямованого впливу на процес вдосконалення професійної підготовки майбутніх офіцерів ракетно-артилерійського озброєння.

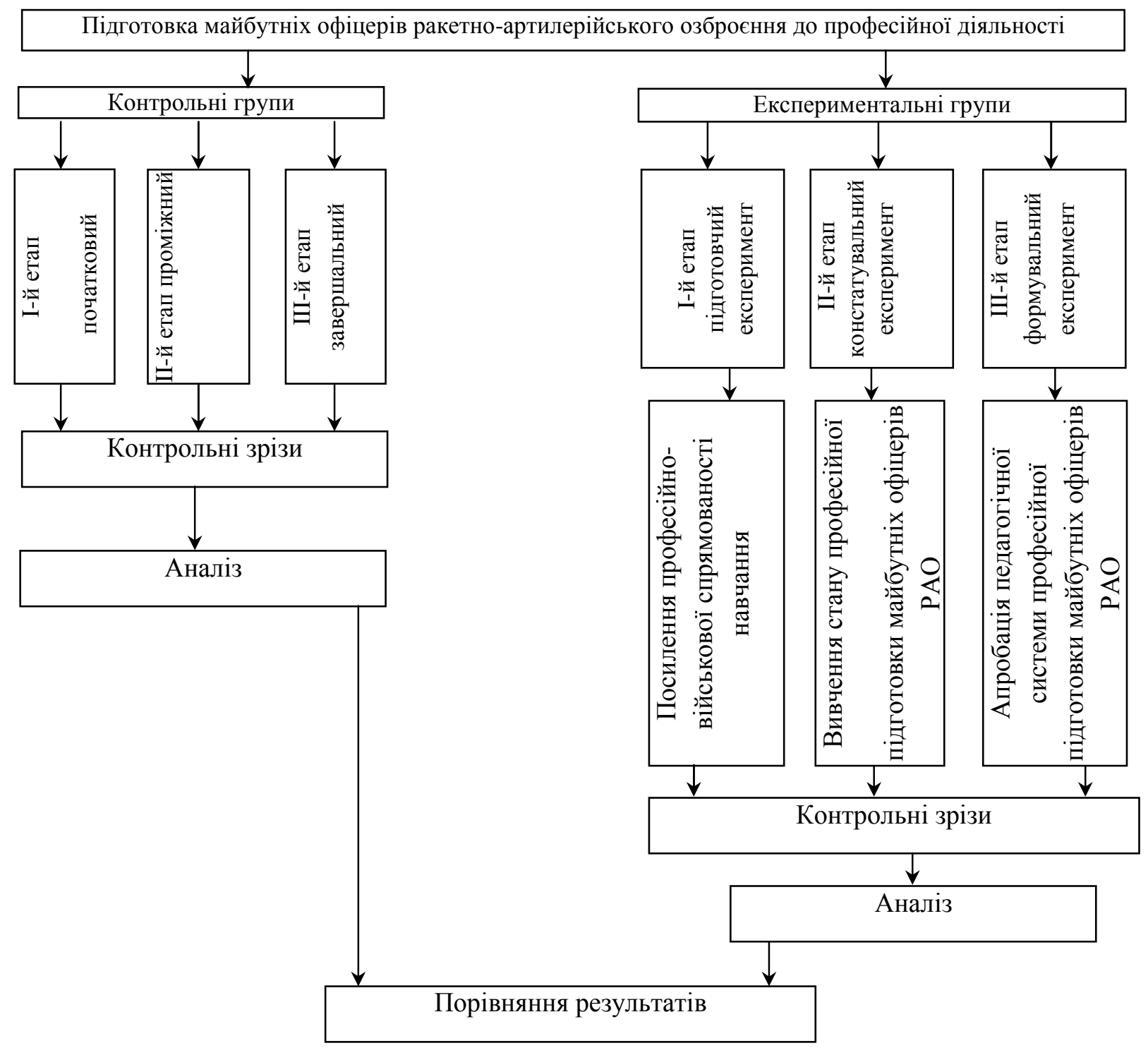

Рис. 1 Алгоритм проведення педагогічного експерименту

Констатувальний етап педагогічного експерименту передбачав вивчення стану професійної підготовки майбутніх офіцерів ракетноартилерійського озброєння у вищих військових навчальних закладах України 3 урахуванням основоположних засад і тенденцій розвитку військових освітніх систем у провідних країнах світу та державної політики в галузі військової професійної освіти. Тому обов'язковою вимогою до професійної підготовки майбутніх офіцерів ракетно-артилерійського озброєння $\epsilon$ орієнтація на 
реалізацію тих цілей і завдань видів збройних сил, що викладені у воєнній доктрині держави. Саме національні інтереси і забезпечення національної безпеки держави є джерелом і потужним чинником розвитку військової освіти України. Підготовка майбутніх офіцерів РАО повинна враховувати потребу в забезпеченні національної безпеки з огляду на збройний конфлікт в східних регіонах України, а також на поширення у світі зброї масового ураження, дестабілізації обстановки в ключових регіонах світу.

Враховуючи зазначене, сформульовано теоретичні положення, які органічно доповнюють теорію і методологію військової професійної освіти. Означене становить підгрунтя теоретичної складової дослідження, яке розпочалося у 2012 році. У процесі проведення констатувального етапу експерименту було реалізовано наступні завдання:

- визначено сучасний стан готовності майбутніх офіцерів ракетноартилерійського озброєння до виконання функціональних обов'язків;

- проведено аналіз основних проблем, що виникають у процесі формування професійної готовності майбутніх офіцерів ракетноартилерійського озброєння;

- спроектовано методичну систему формування професійної готовності майбутніх офіцерів ракетно-артилерійського озброєння під час вивчення дисциплін професійної (загально-професійної, військово-професійної, професійно-спеціальної) підготовки.

Формувальний етап педагогічного експерименту передбачав впровадження в освітній процес вищих військових навчальних закладів педагогічної системи професійної підготовки майбутніх офіцерів РАО в процесі вивчення дисциплін професійної підготовки, яка була розроблена на основі концептуальних положень і структурно-функціональної моделі. Роль цього етапу полягала в діагностуванні доцільності створеної педагогічної системи професійної підготовки майбутніх офіцерів РАО, а мета - у визначенні ефективності запропонованих і розроблених складових зазначеної системи. Необхідність проведення аналітики зумовила діагностування якісних i кількісних характеристик освітнього процесу, завдяки якому здійснювалася професійна підготовка майбутніх офіцерів ракетно-артилерійського озброєння, важливими складовими якої $є$ готовність випускників ВВНЗ до здійснення функціональних обов'язків на високому рівні професійної майстерності, рівень сформованості особистісних якостей, що забезпечують іiі прояв у майбутній професійній діяльності. На даному етапі сформовано контрольні та експериментальні групи курсантів, здійснено аналіз їхньої однорідності щодо успішності вивчення дисциплін професійної підготовки.

Узагальнювальний етап експерименту передбачав перевірку ефективності педагогічної системи професійної підготовки майбутніх офіцерів PAO через порівняння діагностичних зрізів із використання визначених критеріїв. Відповідно до визначених завдань та умов проведення педагогічного експерименту 3 професійної підготовки майбутніх офіцерів РАО здійснено перевірку навчально-методичного забезпечення означеного процесу. 
Висновки та перспективи подальших досліджень. Складність i багатофакторність предмета дослідження зумовили потребу в організації комплексного педагогічного експерименту, який, окрім виявлення позитивних його аспектів і недоліків, дав можливість визначити ефективність нововведень, виявити причинно-наслідкові зв'язки між досліджуваними явищами i процесами, прогнозувати результати професійної підготовки майбутніх офіцерів ракетно-артилерійського озброєння. Подальші розвідки вбачаємо в аналізі результатів функціонування педагогічної системи професійної підготовки майбутніх офіцерів ракетно-артилерійського озброєння.

\section{ЛІТЕРАТУРА}

1. Ашеров, А. Т. (2002) Подготовка, экспертиза и защита диссертаций: Учебное пособие. Харьков : Изд. УИПА, 135 с.

2. Багрій, В.Н.Критерії та рівні сформованості професійних умінь майбутніх соціальних педагогів. Збірник наукових праць Хмельницького інституту соціальних технологій Університету «Україна». URL : http://nbuv.gov.ua/j-pdf/Znpkhist_2012_6_4.pdf (дата звернення: 13.04.2019 р.)

3. Блощинський, I. Г. (2001) Обгрунтування критеріїв і показників ефективності процесу формування адекватної самооцінки курсантів у навчальному процесі ВВЗО. Наукові записки. Серія : педагогіка і психологія. Вінниця : ВАТ «Віноблдрукарня», 4, 74-76.

4. Вікторов, В. Г. (2005) Управління якістю освіти: соціально-філософський аналіз : монографія. Дніпропетровськ : Пороги, 286.

5. Гончаренко, С.У. (2010) Педагогічні дослідження: Методологічні поради молодим науковцям. Київ-Вінниця : ТОВ фірма «Планер», 308.

6. Сльникова, Г. В., Борова, Т. А., Касьянова, О. М., Полякова, Г. А. та ін. (2009) Адаптивне управління : сутність, характеристика, моніторингові системи: Колективна монографія. Чернівці : Технодрук, 572.

7. Загвязинский, В. И., Поташник, М. М. (2004) Как учителю подготовить и провести експеримент: методическое пособие. Москва : Пед. о-во России, 144.

8. Лузан, П. Г., Сопівник, I. В., Виговська, С. В. (2012) Основи науковопедагогічних досліджень : навч. посіб. 4-е вид. доп. Київ : НАКККіМ, 368.

9. Максимюк, С. П. (2009) Педагогіка : навчальний посібник. Київ : Кондор, 670.

10. Сікорський, П., Сікорський, С. (2001) До проблеми визначення критеріїв педагогічного оцінювання. Рідна школа, 8, 3-6.

\section{REFERENCES}

1. Asherov A.T. (2002) Podgotovka, ekspertiza i zaschita dissertatsii: Uchebnoe posobie [Preparation, Expertise, and Defense of Dissertations: Textbook]. Kharkov: UIPA, 135. (in Russian)

2. Bahrii V.N. Kryterii ta rivni sformovanosti profesiinykh umin maibutnikh sotsialnykh pedahohiv [Criteria and Levels of Development of Professional Skills of Future Social Workers]. Zbirnyk naukovykh prats Khmelnytskoho instytutu sotsialnykh tekhnolohii Universytetu "Ukraina" [Scientific Proceedings of Khmelnytskyi Institute of Social Technologies of University "Ukraine"]. URL : http://nbuv.gov.ua/j-pdf/Znpkhist_2012_6_4.pdf (reference date: 13.04.2019). (in Ukrainian)

3. Bloschynskyi I.H. (2001) Obhruntuvannia kryteriiv $i$ pokaznykiv efektyvnosti protsesu formuvannia adekvatnoi samootsinky kursantiv u navchalnomu protsesi VVZO [Substantiation of the Criteria and Indicators of Effective Development of Adequate SelfEstimation of Cadets in Educational Process of HMIE]. Naukovi zapysky. Seriia: pedahohika i psykholohiia [Scientific Proceedings. Series: Pedagogics and Psychology]. Vinnytsia: VAT "Vinobldrukarnia", 4, 74-76. (in Ukrainian) 
4. Viktorov V.H. (2005) Upravlinnia yakistiu osvity: sotsialno-filosofskyi analiz: monohrafiia [Management of Education Quality: Social and Philosophical Analysis: Monograph]. Dnipropetrovsk: Porohy, 286. (in Ukrainian)

5. Honcharenko S.U. (2010) Pedahohichni doslidzhennia: Metodolohichni porady molodym naukovtsiam [Pedagogical Researches: Methodological Advice to Young Scientists]. Kyiv-Vinnytsia: TOV firma "Planer", 308. (in Ukrainian)

6. Yelnikova H.V., Borova T.A., Kasianova O.M., Poliakova H.A. (2009) Adaptyvne upravlinnia: sutnist, kharakterystyka, monitorynhovi systemy: Kolektyvna monohrafiia [Adaptive Management: Sense, Characteristics, Monitoring Systems: Collective Monograph]. Chernivtsi: Tekhnodruk, 572. (in Ukrainian)

7. Zagviazinskiy V.I., Potashnik M.M. (2004) Kak uchiteliu podgotovit i provesti eksperiment: metodicheskoe posobie [How A Teacher Should Prepare and Conduct an Experiment: Handbook]. Moskva: Ped.o-vo Rossii, 144. (in Russian)

8. Luzan P.H., Sopivnyk I.V., Vyhovska S.V. (2012) Osnovy naukovo-pedahohichnykh doslidzhen: navchalnyi posibnyk 4 vyd.dop. [Fundamentals of Scientific and Pedagogical Research: Textbook, $4^{\text {th }}$ Edition]. Kyiv: NAKKKiM, 368. (in Ukrainian)

9. Maksymiuk S.P. (2009) Pedahohika: navchalnyi posibnyk [Pedagogics: Textbook]. Kyiv: Kondor, 670. (in Ukrainian)

10. Sikorskyi P., Sikorskyi S. (2001) Do problem vyznachennia kryteriiv pedahohichnoho otsiniuvannia [On the Problems of Determining the Criteria of Pedagogical Assessment]. Ridna shkola [Native School], 8, 3-6. (in Ukrainian)

\section{РЕЗЮМЕ}

Олег Маслий, кандидат педагогических наук, старший научный сотрудник, Военная академия, г. Одесса

\section{Программа и методика опытно-экспериментальной работы по реализации педагогической системы профессиональной подготовки будущих офицеров ракетно- артиллерийского вооружения}

В статье приведень критерии и показатели оценки эффективности авторской педагогической системы профессиональной подготовки будущих офицеров ракетноартиллерийского вооружения; описаны результаты анализа профессиональной деятельности молодых офицеров ракетно-артиллерийского вооружения - выпускников выстих военных учебных заведений, выбранных базой экспериментального исследования; представлен алгоритм проведения эксперимента по созданию и внедрению в учебный прочесс высших военных учебных заведений указанной системы, который предусматривал 4 этапа (подготовительный, констатирующий, формирующий, обобщающий); подробно отражены результаты каждого этапа экспериментальной работы, кроме обобщающего.

Ключевые слова: высшее военное образование; научное исследование; критерии и показатели оценки эффективности педагогической системы.

\section{SUMMARY}

Oleh Maslii

Candidate of Science (Pedagogical), Senior Scientific Researcher Military Academy, c. Odesa

\section{Program and methodology of research and experimental work on the implementation of pedagogical system of professional training of future officers of missile and artillery armament}


Introduction. The emergence of new demands, made to the professional training of the graduates of higher military educational institutions due to the military conflict in the east of the country and unstable political situation, poses the problem of military experts' willingness for professional work in modern conditions of development of the Armed Forces of Ukraine.

Purpose. Announcing the program and methodology of research and experimental work on the implementation of pedagogical system of professional training of future officers of missile and artillery armament.

Methods of research: analysis, synthesis, systematization of scientific pedagogical manuals, normative documents, generalization and question testing of respondents.

Results. The assessment criteria and indicators are presented of efficiency of the author's pedagogical system of professional training of future officers of missile and artillery armament; the results are described of the analysis of professional work of young officers of missile and artillery armament - graduates from higher military educational institutions which were selected as the base for the experimental research; the algorithm is presented of conducting the experiment on creating and introducing the mentioned system into the studying process of higher military educational institutions, it includes 4 stages (preparatory, ascertaining, shaping, and summarizing); the results of each stage of the experimental work, except for the summarizing stage, are shown in detail.

Originality. The methodology is presented of introducing the author's pedagogical system of professional training of future officers of missile and artillery armament, that can be used in higher military educational institutions for training military experts in any area under the condition of correcting the results of studying according to the educational standards of the relevant speciality.

Conclusion. Complication and multifactorial nature of the research subject caused the need in organising a complex pedagogical experiment which, in addition to revealing it's positive and negative aspects, gave an opportunity to determine the effectiveness of improvements, to reveal causal links between the research phenomena and processes, to predict the results of professional training of future officers of missile and artillery armament.

Keywords: higher military education; scientific research; criteria and indicators of assessment of pedagogical system efficiency. 